\title{
LUTO ANTECIPATÓRIO DO CUIDADOR FAMILIAR NO TRANSPLANTE DE CÉLULAS TRONCO-HEMATOPOÉTICAS
}

Thaísa dos Santos Madeira

Faculdade de Filosofia, Ciências e Letras de Ribeirão Preto,

Universidade de São Paulo

Érika Arantes de Oliveira-Cardoso

Faculdade de Filosofia, Ciências e Letras de Ribeirão Preto,

Universidade de São Paulo

Manoel Antônio dos Santos

Faculdade de Filosofia, Ciências e Letras de Ribeirão Preto,

Universidade de São Paulo

\section{RESUMO}

Este estudo teve por objetivo conhecer as percepções e vivências do acompanhante familiar diante do adoecer e do transplante de células-tronco hematopoéticas (TCTH) à luz da teoria do luto antecipatório. Trata-se de um estudo exploratório com abordagem qualitativa, do qual participaram 11 familiares. As entrevistas individuais foram organizadas pela análise temática e interpretados em três níveis contextuais, envolvendo mudanças intrapsíquicas, interacionais com o paciente e no âmbito familiar/social. Constatou-se que o familiar experimenta sentimentos e reações emocionais consistentes com o processo de enlutamento. As mudanças na interação com o paciente acontecem desde os primeiros sintomas e intensificam-se com a necessidade de fornecer cuidado integral na enfermaria durante o transplante. Transformações na dinâmica familiar acontecem em resposta às perdas de papéis sociais, ocupacionais e seus impactos financeiros. Ademais, o sofrimento experimentado pelo cuidador durante esse processo não é legitimado, tanto pela família quanto pela equipe de saúde, já que do acompanhante se exige que seja uma fonte de apoio inabalável.

Palavras-chave: transplante de células-tronco hematopoéticas; transplante de medula óssea; cuidadores; luto antecipatório; estados emocionais. 


\section{ANTICIPATORY GRIEF OF THE FAMILY CAREGIVER IN HEMATOPOIETIC STEM CELL TRANSPLANTATION}

ABSTRACT

This study aimed to know the perceptions and experiences of family companions facing illness and transplantation of hematopoietic stem cells (HSCT) in light of the theory of anticipatory grief. This is an exploratory study with a qualitative approach, in which 11 relatives participated. The individual interviews were organized by thematic analysis and interpreted at three contextual levels, involving intra-psychic, interactional with the patient and family / social changes. It was found that the family member experiences feelings and emotional reactions consistent with the bereavement process. Changes in patient interaction occur from the earliest symptoms and intensify with the need to provide comprehensive nursing care during transplantation. Transformations in family dynamics occur in response to the loss of social, occupational roles and their financial impacts. Moreover, the suffering experienced by the caregiver during this process is not validated, either by the family or by the healthcare providers, as the companion is required to be an unshakable source of support.

Keywords: hematopoietic stem cell transplantation; bone marrow transplantation; caregivers; anticipatory grief; emotional states. 


\section{LUTO ANTICIPATORIO DEL CUIDADOR FAMILIAR EN EL TRASPLANTE DE CÉLULAS MADRE HEMATOPOYETICAS}

\section{RESUMEN}

Este estudio tuvo como objetivo conocer las percepciones y experiencias del compañero familiar cuando se enfrenta a una enfermedad y el trasplante de células madre hematopoyéticas $(\mathrm{TCMH})$ a la luz de la teoría del duelo anticipatorio. Este es un estudio exploratorio con un enfoque cualitativo, en el que participaron 11 familiares. Las entrevistas individuales fueron organizadas por análisis temático e interpretadas en tres niveles contextuales, involucrando intrapsíquica, interacción con el paciente y cambios familiares / sociales. Se descubrió que el miembro de la familia experimenta sentimientos y reacciones emocionales consistentes con el proceso de duelo. Los cambios en la interacción con el paciente ocurren desde los primeros síntomas y se intensifican con la necesidad de proporcionar atención integral de enfermería durante el trasplante. Las transformaciones en la dinámica familiar ocurren en respuesta a la pérdida de roles sociales, ocupacionales y sus impactos financieros. Además, el sufrimiento experimentado por el cuidador durante este proceso no está legitimado, ni por la familia ni por el equipo de salud, ya que el acompañante debe ser una fuente de apoyo inquebrantable.

Palabras clave: trasplante de células madre hematopoyéticas; trasplante de medula ósea; cuidadores; luto anticipatorio; estados emocionales. 


\section{INTRODUÇÃO}

Atualmente, o Transplante de Medula Óssea (TMO) - ou Transplante de Células Tronco-Hematopoéticas (TCTH) - tem se firmado como o recurso mais adequado e promissor no tratamento de diversas doenças graves, que anteriormente eram consideradas terminais, como as leucemias e outros tipos de neoplasias. Trata-se, no entanto, de um procedimento médico complexo, extenso e agressivo, passível de intercorrências adversas durante seu percurso, com consequências imprevisíveis e potencialmente fatais (Pontes, Guiradello, \& Campos, 2007).

O procedimento tem como base a infusão endovenosa de células-tronco hematopoéticas - CD34, retiradas da medula óssea de um doador compatível, previamente selecionado, em um receptor previamente condicionado. A compatibilidade durante o processo é de extrema importância para o sucesso do transplante. A finalidade desse tratamento é restituir todo o sistema hematopoiético, fazendo com que a medula implantada passe a assumir a produção de células sanguíneas, evitando-se a rejeição (Matsubara, Carvalho, Canini, \& Sawada, 2007). Para que o enxerto recebido seja exitoso, também é fundamental que o novo sistema imunológico adquirido tolere os tecidos do receptor, de modo a evitar a Doença do Enxerto Contra o Hospedeiro (DECH), uma complicação grave e potencialmente fatal, causada pelo ataque das células da nova medula às células do paciente (Pasquini \& Coutinho, 2013).

Segundo Riul e Aguillar (1997), o TCTH é composto por quatro momentos: (1) Preparação pré-transplante: período que engloba a etapa de avaliação do paciente, na qual se realiza o exame pré-admissional, uma avaliação médica completa, a admissão hospitalar do paciente, o preparo pré-transplante e o regime de condicionamento (momento em que é realizada a quimioterapia, com o objetivo de "destruir" a medula óssea doente); (2) Aspiração, processamento e infusão de medula óssea: etapa na qual ocorre a infusão da medula; nesse estágio o paciente experimenta os efeitos adversos do tratamento, tais como alopecia e mucosite; (3) Enxertamento da medula óssea: refere-se à "pega" da medula, o que é identificado quando há indício de funcionamento normal da mesma; e (4) alta hospitalar do paciente e acompanhamento ambulatorial: essa etapa se inicia quando o enxertamento da medula é considerado bem-sucedido e estão superadas as possíveis complicações agudas do transplante, o que possibilita a alta hospitalar e a continuidade do cuidado em regime ambulatorial.

O itinerário cumprido pelo paciente com indicação para TCTH é caracterizado por um período de hospitalização de aproximadamente quatro a seis semanas e pela exposição a experiências dolorosas de ordem física, social e psicológica (Pontes et al., 2007). O diagnóstico de uma doença orgânica que ameaça a continuidade da vida, como o câncer, é acompanhado de vivências penosas de ordem psicológica, que afetam tanto o paciente como seus familiares. A comunicação de uma doença considerada grave e de prognóstico reservado muitas vezes é recebida de forma catastrófica, uma vez que o advento da doença implica em 
uma interrupção abrupta do cotidiano, uma ruptura no fluxo da existência que é sentida como uma pausa indesejável na própria vida, comprometendo planos e arruinando sonhos projetados no futuro (Sá, 2002).

Essa facticidade leva o indivíduo acometido a se ver diante da proximidade da própria finitude. Para a família o instante da comunicação do diagnóstico também é um momento de enorme impacto, pois os familiares veem seu mundo desabar na iminência da perda do ente amado, que tem sua vida interceptada por uma doença potencialmente fatal (Oliveira, Voltarelli, Santos, \& Mastropietro, 2005). Nesse momento marcante e desconcertante da vida familiar, inicia-se um processo simbólico e subjetivo de vivência da perda iminente do ente querido. Para muitas famílias, o diagnóstico pode ser compreendido como uma sentença de morte, um prenúncio ou vaticínio que parece antecipar o infortúnio que está por vir. Estudo que analisou relatos de pessoas que integravam um grupo de apoio ao acompanhante do transplantado de medula óssea constatou que, quando os familiares recebem o diagnóstico de uma doença ameaçadora à continuidade da vida de um ente querido, logo tendem a converter essa comunicação em um prelúdio de morte, associando a doença à finitude e perda iminente (Oliveira-Cardoso, Garcia, Lotério, \& Santos, 2018a). A antecipação da perda do familiar também se faz presente posteriormente, em momentos conturbados que comumente são vivenciados durante o período de internação e declínio das condições de saúde.

Durante as diferentes fases do tratamento são frequentes as intercorrências psiquiátricas, tais como quadros clínicos de depressão, ansiedade, perda da motivação e prejuízos na orientação e organização espaço-temporal. Essas manifestações habitualmente vêm acompanhadas de angústia e intensificação do medo da morte. Na travessia do TCTH podem ocorrer também prejuízos cognitivos, acompanhados por flutuações no nível de consciência e percepção, comprometimento da capacidade de manter a atenção e concentração, desorientação, lapsos e falhas na memória, sintomas que podem ser desencadeados ou agravados pelo processo de hospitalização e isolamento absoluto no qual o paciente é mantido, pela toxicidade medicamentosa e pelo afastamento das atividades diárias (Guimarães, Oliveira-Cardoso, Mastropietro, Voltarelli, \& Santos, 2010).

Além de vivenciar sofrimento psíquico, o paciente padece de dores e pode enfrentar inúmeras complicações decorrentes do tratamento. A inexorabilidade das rotinas rígidas estabelecidas por protocolos rigorosos, o tempo prolongado de confinamento e a necessidade de isolamento em um sistema diferenciado de internação colaboram para o agravamento do sofrimento, sem contar as constantes previsões acerca de possíveis reações e efeitos adversos que podem vir a ocorrer durante o processo, em especial em consequência da radio e quimioterapia, que podem ter impactos significativos e debilitantes (Freitas, Oliveira-Cardoso, \& Santos, 2017). 
Nesse cenário, a presença de um cuidador acompanhante é de suma importância para assegurar as melhores condições possíveis. Essa indicação decorre da tentativa de proporcionar apoio ao paciente hospitalizado e auxílio nos cuidados médicos. Por outro lado, isso leva o familiar a assumir novos papéis, nunca antes desempenhados e para os quais ele ainda não se sente preparado, já que não há um treinamento ou qualificação prévia (Monteiro \& Lang, 2015). O familiar escolhido para ser acompanhante vivencia, junto com o paciente, a mesma rotina de confinamento e isolamento dentro de uma unidade hospitalar, acompanhando os riscos e complicações presentes em todas as fases da hospitalização. A necessidade de abandonar sua rotina para permanecer 24 horas ao lado do paciente acaba comprometendo suas responsabilidades de cuidado em relação ao restante da família (Diefencach, Toscan, \& Pavão, 2008; OliveiraCardoso et al., 2018a; Von Ah, Spath, Nielsen, \& Fife, 2015). Nos casos de pais cuidadores, principalmente quando os pacientes são crianças ou adolescentes, a preocupação do cuidar torna-se tão imperiosa que passa a consumir quase que exclusivamente suas energias e ocupar o foco de atenção parental (Sampaio, 2011). O cuidador abdica de cuidar de si para se doar ao outro, acentuando sua situação de vulnerabilidade, o que pode dar margem para o seu próprio adoecer físico, psíquico e emocional (Passos, Pereira, \& Nitschke, 2015; Sampaio, 2011).

As famílias têm de lidar com a perda da vida "normal", que geralmente é identificada com a rotina que vivenciavam antes de receberem o diagnóstico, sendo obrigadas a elaborar o luto pela ruptura do convívio cotidiano que mantinham enquanto organização familiar antes do aparecimento da doença. Esse fardo é acrescido do luto pelo rompimento momentâneo dos sonhos e da confiança em um futuro tranquilo e livre de ameaças. Juntamente com os eventos estressores e a fragilização da esperança, os acompanhantes passam a encarar a destruição da crença de que doenças fatais só ocorrem com os outros e não com um ente próximo. Frequentemente ocorre uma desorganização total da unidade familiar (Rolland, 1998), sendo que nem sempre os acompanhantes do paciente estão preparados para enfrentar as novas e desafiadoras situações impostas pelo regime de isolamento protetor do TCTH (Matsubara et al., 2007).

Estudo realizado por Rocha et al. (2016) mostrou que a rotina dos pacientes, assim como dos acompanhantes, é abruptamente interrompida, ocasionando forte impacto psicossocial devido ao afastamento dos estudos, do emprego, do convívio familiar, entre outras perdas que podem surgir nesse período. As questões financeiras e de provimento das necessidades materiais da família passam a ser fatores determinantes na maioria dos casos, pois influenciam diretamente na qualidade de vida do paciente pós-hospitalização, na medida em que atenuam as condições de vulnerabilidade em comparação com aqueles que enfrentam dificuldades de subsistência.

Quando se está diante de uma doença potencialmente fatal, as perdas vivenciadas podem ser de ordem simbólica ou concreta. Independentemente de sua natureza, essas perdas desencadeiam a vivência do luto, um processo 
esperado tanto para pacientes quanto para seus familiares. Segundo Fonseca (2014), o luto é um processo de construção de significado, que tem início a partir do momento em que é recebido o diagnóstico de uma doença crônica ou terminal. A experiência do enlutamento é intensificada pelas perdas atuais que já estão ocorrendo e incrementada pelas perdas futuras, que incluem dificuldades financeiras, mudanças de papéis sociais, alterações irreversíveis da imagem corporal, sofrimento físico e emocional, dentre outras.

A sensibilidade a perdas ocorridas no passado e que não puderam ser devidamente elaboradas pode ser reativada, potencializando a vivência de um novo luto. Assim, a família tem de lidar com alterações nas relações estabelecidas entre seus membros, mudanças de estilo de vida e a transformação de planos e sonhos projetados no futuro que podem não se concretizar. A esse processo se denomina de "luto antecipatório", considerando que ele ocorre quando a pessoa gravemente doente ainda está presente. No luto antecipatório, de acordo com Fonseca (2014), podem ocorrer as mesmas reações que são identificadas no luto pós-morte, que compreendem: choque, negação, ambivalência, revolta, negociação, depressão e adaptação.

O choque ocorre quando a pessoa sofre um abalo e, em consequência, experimenta desespero e/ou sensação de atordoamento, entorpecimento, confusão, com uma gama de reações que podem variar desde a apatia à agitação e hiperatividade. A negação pode ser entendida como um mecanismo de defesa que é mobilizado na tentativa automática de continuar a vida como se nada houvesse ocorrido, denotando incapacidade de aceitar a nova realidade marcada pela possibilidade de perda iminente. A ambivalência é expressa quando a pessoa se encontra dividida por um dilema entre a aceitação da doença e da perda iminente e, no outro extremo, a proeminência da negação. A revolta ocorre quando predomina o ressentimento, a raiva e o protesto; na vigência desses afetos negativos podem surgir também sentimentos de culpa $e$ autorrecriminação em relação ao que foi ou não dito, ou que foi ou não realizado até então. A negociação é caracterizada pela tentativa de realizar algum acordo que sirva de compensação e promova algum tipo de satisfação vicária pela saúde perdida; nesse momento de barganha, a fé e a esperança são fortemente expressas. A depressão é um estágio no qual a pessoa vivencia uma profunda tristeza e encontra-se fisicamente abatida e apática. A adaptação ocorre quando há aceitação da realidade da perda iminente e das mudanças que ela involucra, transformações tanto positivas como negativas que decorrem do processo de adoecimento; essa etapa dá início à elaboração da perda, culminando o trabalho de luto, que é concluído quando a realidade prevalece.

Cabe a ressalva de que a expressão fases do luto não é apropriada porque pode levar a uma compreensão equivocada do processo de enlutamento, como se tratassem de períodos cronologicamente lineares e estanques. A compreensão do enlutamento deve vir acompanhada da noção de que não se trata de um processo sequencial e linear, e muito menos único e homogêneo para todos os 
indivíduos que vivenciam situações de perda reais ou simbólicas. Nem todas as pessoas passam pelas "fases" tais como foram descritas anteriormente, uma vez que a vivência do processo de enlutamento é significada de maneira singular, sendo, portanto, necessário considerar a individualidade de cada paciente para que se possa compreender o caminho percorrido, de acordo com sua capacidade peculiar de subjetivação e simbolização do sofrimento (Silva, Santos, \& OliveiraCardoso, 2019).

Em estudo realizado por Oliveira-Cardoso e Santos (2013) com 17 pacientes com câncer hematológico, foi constatado que os participantes, diante do diagnóstico, vivenciaram manifestações características do processo de luto antecipatório. As reações presentes na tomada de decisão pelo TCTH foram similares às que frequentemente são despertadas no processo de luto. Essas reações envolviam emoções e sentimentos intensos: choque, negação, revolta, ambivalência, revolta e barganha, depressão e aceitação. O choque foi descrito como uma sensação de incredulidade com a situação vivenciada. A negação ocorria, em muitos casos, pela não correspondência do diagnóstico com o estado físico percebido pelo paciente e com sua sintomatologia, e se apresentou como uma estratégia de defesa, como um tempo de suspensão necessário para elaborar e aceitar o diagnóstico e, assim, se preparar para a nova realidade. A ambivalência mostrouse como um desejo de enfrentar a situação em busca de um aumento da sobrevida, em contraste com o sentimento de desesperança e desconfiança em relação ao sucesso do transplante. A revolta apareceu desde a busca por uma explicação ("por que isso está acontecendo comigo?") até o questionamento em relação à atitude dos médicos, devido ao modo como o diagnóstico foi comunicado. A barganha se deu por meio de acordos realizados com entes reais ou imaginários, e que comumente são valorizados pelo paciente ou pela família, podendo ser personificados pelo médico da equipe, por Deus ou por um santo de devoção. A depressão se manifestou por meio da dificuldade de elaborar o sofrimento resultante do diagnóstico, enquanto muitas vezes a pouca informação que se tinha sobre a doença levava à autoculpabilização.

De acordo com Fonseca (2014), o processo do luto antecipatório pode ser apreciado por meio de quatro perspectivas diferentes: a perspectiva do paciente; a perspectiva dos membros da família ou da rede social do paciente, formada por pessoas com as quais ele mantém uma relação próxima, com vínculos considerados fortes e seguros; a perspectiva de pessoas que de alguma forma mantêm um vínculo com o paciente, mas que não têm intimidade suficiente com ele; e a perspectiva do cuidador. Esse processo se dividiria em três níveis contextuais: intrapsíquico, interacional com o paciente e familiar/sistêmico. Esses contextos são válidos para todas as pessoas que fazem parte do processo de enlutamento: o doente, seus familiares e amigos íntimos, seus cuidadores e as pessoas de sua rede social, levando-se em conta a especificidade de cada pessoa e de cada situação. Em relação aos processos intrapsíquicos a experiência do luto antecipatório se divide em quatro categorias inter-relacionadas, segundo Fonseca (2014): 
a) Consciência sobre a ameaça de morte gradual e adaptação à situação: o indivíduo, na medida em quem que se conscientiza da iminente ameaça de perda, tem de lidar com os efeitos dessa consciência. O enlutado recebe informações acerca do tratamento e de suas possíveis implicações e consequências. Assim, na medida em que o processo avança, passa por uma reorganização interna, desenvolvendo novas formas de lidar com as perdas irreparáveis e com outros aspectos trazidos pela doença, adaptando-se gradualmente ao papel de enlutado nessa forma antecipatória.

b) Processos afetivos: as principais reações experimentadas são manifestações de culpa, tristeza, depressão, raiva, hostilidade e ansiedade. As tarefas características dessa categoria são: enfrentar o estresse suscitado pela situação e a tentativa de regulação das reações emocionais com as demandas incompatíveis da doença; vivenciar as reações emocionais decorrentes do processo de enlutamento e de perdas vividas anteriormente; lidar com a ansiedade e o medo suscitado pela ameaça constante de separação; efetuar o gradual desligamento da imagem que se tinha da pessoa enferma até o adoecimento, assim como de suas emoções, desejos, fantasias, sonhos, planos, crenças e expectativas, que estão associados à imagem do doente; e diferenciar-se da pessoa enferma, ao tomar consciência de que ela irá morrer, ao passo que o enlutado continuará vivo.

c) Processos cognitivos: diante das perdas irremediáveis ocorridas e da proximidade da morte, os familiares passam a reconhecer a necessidade de mudar sua própria identidade, retificando os papéis que desempenhavam e exercitando os novos que estão tendo que assumir. Desse modo, preparam-se para a realidade que se aproxima e tendem a colocar a dor do doente em evidência, refletindo sobre sua própria morte, buscando, por meio da espiritualidade/religiosidade, elaborar um significado ou explicação que traga alento para o momento vivido, o que pode auxiliá-los a lidar com o tempo restante com o doente.

d) Planejamento do futuro: consiste em assumir que, no cenário futuro, a pessoa amada não estará mais presente. Ao experimentar as reações associadas a tal perda pode-se planejar futuras perdas e mudanças referentes ao período pósmorte, e assim planejar situações práticas que precisam ser enfrentadas antes e depois da morte. É válido incluir o doente nesse planejamento do porvir, de forma a lhe permitir manter certo controle sobre a situação.

Já os processos interacionais com a pessoa enferma aludem às interações dos familiares e dos amigos íntimos com o adoecido, o que inclui o seu acompanhamento, cuidados dispensados e apoio na resolução de pendências e conflitos. A experiência do luto antecipatório nesse contexto é subdividida em três categorias (Fonseca, 2014):

a) Direcionar energia, atenção e comportamentos ao doente: permite às pessoas envolvidas no processo de enlutamento, no período pós-morte, experimentarem um sentimento de contemplação por terem proporcionado uma atenção 
adequada ao doente, por meio da comunicação, interação e presença de significados presentes na relação, além de organizarem juntos com o doente uma escala de prioridades de necessidades a serem satisfeitas.

b) Resolução da relação pessoal com o doente: possibilita que as pessoas envolvidas no enlutamento não se sintam sobrecarregadas com sentimento de culpa, principalmente no período pós-morte. Engloba o trabalho de fechar as questões até então pendentes ou inacabadas, comunicar o que o doente significa em suas vidas, compartilhar memórias de experiências comuns, fazer planos e pactos com o doente que possam ser cumpridos após a sua morte e, no tempo apropriado, se despedir dele e permitir que ele se vá em paz.

c) Auxiliar o doente nas suas questões: o que significa auxiliá-lo em seu luto antecipatório, fornecendo apoio psicossocial, ajudando-o a identificar suas necessidades, atender a seus últimos desejos, ajudar na resolução de problemas e de questões inacabadas, a fim de possibilitar a capacidade de se despedir da vida quando chegar o tempo apropriado.

Por fim, nos processos familiares e sistêmicos, o luto antecipatório incita processos sistêmicos nos níveis familiar e social, sendo necessário que a família se aceite sem contar mais com a possibilidade de o membro doente desempenhar os antigos papéis no sistema familiar. Também é imperativo que os membros saudáveis assumam novos encargos e responsabilidades, ocupando os espaços deixados pela incapacitação do membro adoecido e por sua futura ausência. Os familiares também precisam promover alianças e aprender a incrementar a rede de suporte social, somando forças e aglutinando pessoas e instituições, a fim de proporcionar melhor atendimento às necessidades do paciente. Também é desejável que os familiares recebam amparo e auxílio espiritual dos serviços religiosos, para que tudo corra de acordo com os desejos manifestados em vida pelo doente (Fonseca, 2014).

Armoogum, Richardson e Armes (2013) observaram que os cuidadores de pacientes que são submetidos ao TCTH vivenciam impacto negativo em sua saúde física e psicológica, que resulta em necessidades de suporte não atendidas. As demandas insatisfeitas favorecem o agravamento da morbidade psicológica. Dessa forma, considerando que o cuidador familiar também vivencia o processo de enlutamento, é necessário atentar e dar suporte às suas necessidades específicas, como as de receber cuidado emocional, o qual pode ser proporcionado por profissional capacitado a acolher, ouvir e auxiliar no processo de elaboração do luto antecipatório (Fonseca, 2014).

Monteiro e Lang (2015) argumentam que o cuidador principal, na maior parte das vezes, é a pessoa que mais necessita de suporte, uma vez que precisa ser lembrado de sua própria existência. No entanto, apesar da vulnerabilidade inerente ao desempenho do papel crítico de cuidador, a literatura disponível nesse campo ainda é incipiente, sendo escassos os estudos que se concentram na experiência do cuidador, e ainda menor a quantidade de pesquisas que se 
dedicam a compreender o luto antecipatório vivenciado pelo cuidador durante o período de transplante. Essas evidências justificam a proposição de novos estudos que possam lançar um olhar para aqueles que desempenham o papel de acompanhante/cuidador no TCTH.

Considerando o exposto, este estudo teve por objetivo conhecer as percepções e vivências do acompanhante familiar diante do adoecimento e do TCTH à luz da teoria do luto antecipatório.

\section{MÉTODO}

Trata-se de um estudo exploratório, amparado na abordagem de pesquisa qualitativa. Adotou-se, como estratégia metodológica, a realização de estudos de caso múltiplos. Como descrito por Alves-Mazzotti (2006), o "caso" selecionado deve ser crítico, extremo, único, ou então revelador, sendo que, em quaisquer dessas situações, deve-se manter o foco em fenômenos sociais que pareçam ser relevantes e complexos. Por outro lado, os estudos de caso devem se aprofundar em fenômenos pouco investigados e se empenhar na identificação de categorias de observação que possam gerar hipóteses para fundamentar possíveis estudos futuros.

\section{PARTICIPANTES}

A amostra foi composta pelos acompanhantes de pacientes atendidos em uma Unidade de Transplante de Medula Óssea (UTMO), localizada em um hospital público universitário do interior paulista, vinculado ao Sistema Único de Saúde (SUS). Os critérios de inclusão dos participantes foram: ser cuidador principal de paciente submetido ao TCTH, ter idade superior a 18 anos, prestar cuidados diretos ao paciente desde o início do transplante, manter-se vinculado ao ambulatório da UTMO no pós-TCTH imediato e ter disponibilidade para colaborar de maneira voluntária com a pesquisa.

Como esperado de acordo com a literatura da área, a amostra de acompanhantes foi composta majoritariamente por mulheres. O grau de parentesco mais prevalente foi de cônjuge e a doença de base mais frequente foi leucemia. Somente uma das participantes alegou não ter religião. A maioria dos participantes era procedente de outro município, distante da cidade na qual era dispensado o tratamento. Sete dos 11 familiares entrevistados trabalhavam, o que implicou em seu afastamento laboral, com as implicações emocionais, sociais e econômicas que essa necessidade desencadeia.

A caracterização detalhada da amostra pode ser visualizada na Tabela 1. 
Tabela 1.

Caracterização demográfica e clínica dos participantes segundo o sexo, idade, grau de parentesco, procedência, ocupação, religião e diagnóstico do membro familiar acometido. Ribeirão Preto, SP, Brasil, 2018.

\begin{tabular}{|c|c|c|}
\hline Variáveis & $\mathbf{N}$ & $\%$ \\
\hline \multicolumn{3}{|l|}{ Sexo } \\
\hline Masculino & 9 & 81,81 \\
\hline Feminino & 2 & 18,18 \\
\hline Total & 11 & 100,0 \\
\hline \multicolumn{3}{|l|}{ Idade } \\
\hline $20-39$ & 2 & 18,18 \\
\hline $40-59$ & 7 & 63,63 \\
\hline $60-64$ & 2 & 18,18 \\
\hline \multicolumn{3}{|l|}{ Grau de parentesco } \\
\hline Cônjuge & 5 & 45,45 \\
\hline Mãe & 4 & 36,36 \\
\hline Irmã & 1 & 9,09 \\
\hline Sogra & 1 & 9,09 \\
\hline \multicolumn{3}{|l|}{ Procedência } \\
\hline Cidade do tratamento & 1 & 9,09 \\
\hline Outros municípios & 10 & 90,90 \\
\hline \multicolumn{3}{|l|}{ Ocupação } \\
\hline Sim & 7 & 63,63 \\
\hline Não & 4 & 36,36 \\
\hline \multicolumn{3}{|l|}{ Religião } \\
\hline Sim & 10 & 9,09 \\
\hline Não & 1 & 90,90 \\
\hline
\end{tabular}


Tabela 1. Continuação.

\begin{tabular}{l|c|c} 
Variáveis & N & $\%$ \\
Diagnóstico & & \\
$\quad$ Leucemia Mieloide Crônica (LMC) & 7 & 63,63 \\
$\quad$ Outros & 4 & 36,36 \\
\hline
\end{tabular}

\section{INSTRUMENTOS}

\section{ROTEIRO DE ENTREVISTA SEMIESTRUTURADA}

Trata-se de um roteiro especialmente elaborado para atender aos objetivos deste estudo. O propósito desse roteiro foi coletar informações que permitissem caracterizar as mudanças ocorridas na vida do cuidador familiar de paciente submetido ao TCTH. Para isso, foram abordados, após a coleta dos dados sociodemográficos, aspectos relativos à história pessoal dos participantes, os antecedentes de relacionamentos familiares, a vida atual, as repercussões geradas pela doença do familiar, o processo de escolha do acompanhante e a experiência do TCTH na perspectiva do cuidador, e seus projetos de vida e planos futuros.

\section{DIÁRIO DE CAMPO}

Segundo Weber (2009), o diário de campo é um instrumento com o qual o pesquisador se dedica a registrar suas impressões, dia após dia e ao longo de toda a experiência investigativa. As notas de campo têm por base a realização de observações diretas dos comportamentos de um determinado grupo. Neste estudo, por meio das anotações sistemáticas no diário de campo, foi possível levantar dados pertinentes ao contexto investigado - o universo do cuidador de paciente submetido ao TCTH - e as vivências e percepções de seus protagonistas, assim como o movimento do pesquisador inserido nesse contexto.

\section{PROCEDIMENTO}

Por se tratar de uma investigação que se aconteceu em contexto naturalístico, adotou-se como princípio norteador o respeito aos interesses e necessidades dos participantes e da instituição hospitalar na qual o estudo foi conduzido. O projeto foi aprovado pelo Comitê de Ética em Pesquisa da instituição acadêmica a qual os pesquisadores estão vinculados, de acordo com o disposto na Resolução $n^{\circ}$ $466 / 12$, que regula a pesquisa que envolve seres humanos.

Os dados foram coletados com acompanhantes que passavam por diferentes momentos do período de internação junto ao familiar adoecido. Em alguns casos, a pessoa acometida já havia sido submetida ao TCTH, enquanto que, em outros, os familiares hospitalizados ainda passariam pelo procedimento, mas já se 
encontravam na fase pré-TCTH. As entrevistas foram realizadas individualmente e aconteceram em um ambiente reservado. As conversas foram audiogravadas, mediante anuência dos participantes. Seguiu-se o roteiro semiestruturado previamente estabelecido, aplicado em situação face a face. Cada entrevista teve, aproximadamente, uma hora de duração.

As entrevistas foram transcritas na íntegra e literalmente, constituindo o corpus da pesquisa, complementado pelas anotações do diário de campo. Posteriormente, os dados foram submetidos à análise temática indutiva, segundo Braun e Clarke (2006), procedimento que permitiu identificar concepções, crenças, valores, motivações e atitudes comuns entre os participantes do estudo. Para essas autoras, a análise temática é bastante fluida e flexível, e por isso se mostra útil e adequada para a pesquisa qualitativa em Psicologia, quando se intenta capturar os significados de uma experiência por meio dos temas recorrentes que emergem nos relatos. É um método que identifica, analisa e relata padrões (temas) nos dados obtidos, de forma que o pesquisador tem um papel ativo ao longo desse processo. A análise temática é minimamente organizada e descreve o conjunto de dados em detalhes, sendo orientada e dirigida pelo interesse teórico do pesquisador. O processo de análise é dividido em seis etapas:

a) Familiarizar-se com os dados: Transcrever, ler e reler os dados e anotar as ideias iniciais (busca de significados e padrões).

b) Gerar códigos iniciais: Coleta e codificação das características relevantes dos dados de forma sistemática em todo o conjunto de dados. Organizar os dados em grupos significativos. Os dados codificados diferem das unidades de análise (os temas), que são mais amplas. Os temas são desenvolvidos na próxima fase.

c) Buscar temas: Início da análise interpretativa dos códigos. Os códigos diferentes podem se combinar para formar um tema abrangente. Pode ser útil nesta fase usar representações visuais que ajudam a classificar os diferentes códigos em temas, como tabelas, mapas temáticos, entre outros recursos facilitadores da visualização.

d) Rever os temas: Refere-se à revisão e ao refinamento dos códigos extraídos para cada tema, ou seja, verificar se eles se referem a um padrão coerente e se apresentam validade dos temas individuais em relação a todo o conjunto de dados. Os dados que compõem os temas devem ser coerentes, e os temas diferentes devem apresentar distinções claras e identificáveis. No final dessa fase, é necessário saber quais são os diferentes temas e como eles se articulam em relação a todo o conjunto de dados.

e) Definir e nomear temas: Definir e aperfeiçoar os temas apresentados. Analisar os dados, identificar a "essência" e a especificidade de cada tema e gerar definições claras e criar nomes para cada um deles. É importante não obter um tema muito amplo, diverso e complexo. 
f) Produzir o relatório: Análise final dos temas levantados. Selecionar exemplos atrativos e pertinentes para exemplificar cada tema. Relacionar a análise com a questão norteadora da pesquisa e com a literatura, visando a articular o objetivo do estudo, a fundamentação teórica adotada e os achados empíricos.

Os resultados foram sistematizados nas categorias temáticas e interpretados com base na teoria do luto antecipatório, buscando-se desvelar as vivências e percepções dos cuidadores de pacientes submetidos ao TCTH.

\section{RESULTADOS E DISCUSSÃO}

A partir da análise das entrevistas foi possível constatar algumas convergências e divergências entre os relatos dos 11 participantes, no que concerne à experiência de assumir e desempenhar o papel de acompanhante de paciente submetido ao TCTH. Essas convergências e divergências, que serão discutidas na sequência, foram organizadas em três categorias, que por sua vez se subdividiram em subcategorias. Serão usados nomes fictícios para identificar familiares e pacientes.

\section{MUDANÇAS INTRAPSÍQUICAS}

Foram consideradas mudanças intrapsíquicas as percepções de transformações que ocorreram internamente, segundo os acompanhantes, desde o momento da descoberta do diagnóstico até o período que inclui a hospitalização.

\section{REAÇÕES EMOCIONAIS DESPERTADAS PELO DIAGNÓSTICO}

Foi possível perceber que as reações emocionais foram compostas por um misto de sensações disfóricas, como sentimentos de desespero e medo, principalmente relacionados à morte iminente, marcados também por reações de tristeza, choro e choque diante da notícia do adoecimento do ente querido. Uma das participantes declarou:

Aí, sabe quando acaba... Quando você perde a esperança de tudo? Aí eu já comecei a por na cabeça que eu ia ter que criar o neném dela. Falei: "Gente, o caso dela é muito grave, se essa menina morrer, meu Deus, eu vou ter que criar essa criança". Aí, sabe quando você tem um monte de coisa que passa na sua cabeça? (Luana, 51 anos, sogra de Vera, diagnosticada com LMC).

Este excerto de fala mostra o quanto o recebimento do diagnóstico de uma doença neoplásica pode ser impactante para o familiar. Os demais participantes também descreveram esse momento como uma experiência chocante, na qual vivenciaram sentimentos extremos, principalmente de tristeza e desamparo frente à finitude, com a quebra da fantasia onipotente da "invulnerabilidade familiar" (Oliveira-Cardoso \& Santos, 2013): 
A gente custa a acreditar porque a gente... É aquilo que a gente sempre imagina, a gente vê acontecer muito próximo da gente, mas nunca acredita que vai acontecer com a gente, né? (Meire, 51 anos, mãe de Pedro, diagnosticado com LMC).

De acordo com Oliveira-Cardoso et al. (2018a), o diagnóstico de uma doença potencialmente fatal é perturbador porque faz com que a família vivencie um permanente estado de alerta devido ao medo suscitado pelo contato com a finitude da vida do paciente, antecipando a possibilidade de uma perda que pode surpreender a qualquer momento. O impacto do diagnóstico é mais intenso se o familiar reviver outros lutos relacionados ao câncer, que já constem em seu repertório vivencial:

[...] Assim, na minha família todas as pessoas morrem de câncer. A minha avó morreu de câncer, o meu avô morreu de câncer, minha mãe morreu de câncer e minhas tias, irmãs da minha mãe, morreram todas de câncer. Minha sogra morreu de câncer, então eu acompanhei muito câncer desde pequena. Então, quando eu ouço a palavra câncer, eu relaciono à morte (Isaura, 52 anos, mãe de Regiane, diagnosticada com LMC).

Assim, diante da ameaça iminente de separação ou morte, instaura-se a experiência do luto antecipatório. A vivência desse processo psicológico de luto apresenta reações semelhantes às que são identificadas no luto pós-morte, tais como o choque, presente na fala de Vera e na descrição dos outros participantes, quando relatam como se sentiram no momento do recebimento da notícia de que o ente estava doente (Fonseca, 2014).

O diagnóstico de uma doença potencialmente terminal também pode fazer emergir o sofrimento pelas perdas do futuro não vivido. Em alguns casos, o impacto do diagnóstico desorganiza:

[...] a gente pensa [chora copiosamente] que a gente nunca vai passar por uma situação dessas. Ele é uma pessoa que, nesses 53 anos, ele tem 33 anos de firma, ele não tem um atestado e um afastamento do trabalho. Assim, a gente ficou triste porque agora que a gente ia... Ele aposentando, a gente podia passear, aproveitar melhor, ele poderia começar a viver a vida dele, porque ele deu a vida no serviço, ele não viu a vida dele passar, ele não viu nada, só deu o sangue no serviço (Janaína, 47 anos, esposa de Carlos, diagnosticado com Mieloma Múltiplo).

\section{REAÇÕES EMOCIONAIS POTENCIALIZADAS POR OUTRAS EXPERIÊNCIAS ADVERSAS}

A reação de perplexidade e revolta dos acompanhantes pode ser exacerbada por outras crises familiares, como aparece no relato de Isaura, que conta como foi o impacto de receber o diagnóstico de LMC da filha somado à descoberta quase 
concomitante de que o filho tinha HIV, o que se confirmou após os exames feitos para verificar sua compatibilidade para ser o eventual doador de medula óssea para a irmã.

Aí você recebe uma notícia de que a sua filha tem leucemia, daqui a pouco você recebe uma notícia de que é Filadélfia e que é um tipo muito agressivo, e aí depois você vai fazer os testes para ver qual dos irmãos que vai ser compatível, você descobre que um tem HIV (Isaura, 52 anos, mãe de Regiane, diagnosticada com LMC).

De acordo com Simoneau et al. (2013), o cuidador familiar é impactado significativamente no seu bem-estar físico, emocional e social.

Eu era uma pessoa, assim, sabe? De domingo a Ana Júlia falava: "Mãe, você vai colocar fogo na chácara", ela falava brincando, porque eu sou uma pessoa muito alegre... Era, né, tomava uma cervejinha. E agora, não, do dia em que falou que ela... que ela estava com leucemia, eu... eu acho que acabei morrendo por dentro, porque é muito dolorido, muito (Noeli, 62 anos, mãe de Ana Júlia, diagnosticada com LMC).

O estresse familiar também permeia os relatos que reportam alterações corporais percebidas pelo cuidador, por meio da desregulação menstrual, aumento da suscetibilidade à fadiga crônica, perda de peso e queda de cabelo.

[...] cansaço, eu estou... eu perdi cinco quilos, perdi cinco quilos. Mas, normal, dor eu não tenho, cansaço existe, lógico, mas o que mais mexeu comigo é o meu emocional, eu não estou... [chora]. Eu não estou bem (Meire, 51 anos, mãe de Pedro, diagnosticado com LMC).

Desse modo, pode-se depreender facilmente das falas que o fato de conviver com o diagnóstico e os rigores do tratamento potencializa inúmeras mudanças intrapsíquicas, majoritariamente disfóricas, o que evidencia que pode ser um momento devastador para o acompanhamento do paciente do TCTH. De acordo com Fonseca (2014), ao receber o diagnóstico de uma doença potencialmente terminal, as experiências do enlutado são intensificadas pelas perdas ocorridas no passado, as perdas presentes e também pelas perdas futuras relacionadas ao que não poderá ser concretizado.

\section{MUDANÇAS INTERACIONAIS COM O PACIENTE}

Referem-se às alterações percebidas na relação entre acompanhante e paciente. Pode-se notar que essas mudanças tiveram início com a vivência dos novos papéis: de cuidador e de paciente, instaurando um novo padrão de relacionamento para o qual ainda não estavam preparados. Segundo Fonseca (2014), os processos de mudança na interação com a pessoa adoecida consistem 
no envolvimento muito próximo e presente, que inclui acompanhar e passar longos intervalos de tempo com a pessoa amada, a fim de encorajá-la a persistir em sua luta pela vida, auxiliá-la a resolver os conflitos existentes e atenuar seu sofrimento.

\section{DIRECIONAMENTO DE ENERGIA, ATENÇÃO E COMPORTAMENTOS PARA CUIDAR DA PESSOA ADOECIDA}

Nota-se que o familiar acompanhante tende a fazer de tudo para prover o bemestar do doente, direcionando sua energia física e emocional para adquirir habilidades de cuidado, em um cenário no qual tudo parece ser novidade e solicita prontidão para o aprendizado. Há envolvimento e direcionamento total para o ato de cuidar, porém essa abnegação pode vir acompanhada por um processo de despersonalização, perda de identidade do acompanhante - que não se reconhece como sujeito de necessidades, sentimentos e desejos, assim como seu sofrimento tende a permanecer velado e não validado, reconhecido e diferenciado pela equipe e pelo próprio paciente.

[...] eu até digo: "Olha, filha, por favor, se você tiver sentindo alguma coisa, você tem que me falar, para eu chegar lá fora e falar para a enfermeira. Não fique tentando disfarçar para me poupar não, porque eu estou aqui para lhe ajudar, estou aqui para, se você tiver sentindo uma dor na unha, dizer: "Ai, mãe, eu tô sentindo uma dor na unha", e eu poder chegar para a enfermeira e dizer: "Olha, ela tá sentindo uma dor na unha" (Karla, 40 anos, mãe de Camila, diagnosticada com Esclerose Sistêmica).

Foi constatada, entre os participantes, uma preocupação acentuada e constante, que é percebida por meio do interesse frequente em querer saber como a pessoa adoecida se encontra e se ela necessita de algo, como aparece claramente no relato de Karla, no qual essa mãe questiona a todo momento sua filha para saber se pode fazer algo a mais pelo seu bem-estar. Segundo Sá (2002), a rotina que o cuidador vivencia dentro do hospital é direcionada para atender as necessidades do outro e, desse modo, ele pode ficar aprisionado pela fantasia de não ser suficientemente bom para desempenhar seu papel. Lidar com as mudanças do dia a dia não é fácil, especialmente em um cenário instável no qual o estado de saúde da pessoa adoecida é imprevisível e volátil. Pode-se dizer que o cuidado é fornecido pelo familiar acompanhante como se estivesse a todo momento "pisando em ovos". Essa obrigação de estar sempre alerta exaure as energias do acompanhante, uma vez que a sua atenção é direcionada para o paciente para evitar que o pior venha a ocorrer, como exposto na fala de Tamara:

[...] no começo, quando ele foi para casa na primeira vez, depois de 40 dias no hospital, ele foi e levou uma lista de tudo que podia e tudo que não podia fazer, e eu fiquei com medo, porque, assim, poderia prejudicar ele e eu pensei que eu não 
fosse dar conta, entendeu? (Tamara, 20 anos, esposa de João, diagnosticado com LMC).

O cuidado de um paciente submetido ao TCTH, mesmo aqueles que já passaram por outros processos anteriores de hospitalização prolongada, é diferenciado. Conforme Sá (2002), o familiar escolhido para desempenhar o papel de cuidador já é alguém impactado pela doença, e as informações que recebe sobre o TCTH são insuficientes diante das necessidades e dificuldades que vão emergindo no dia a dia. De todos os participantes desta pesquisa, Tamara foi a única que nunca havia experimentado, em qualquer outro momento de sua vida, o papel de acompanhante de um paciente hospitalizado, e essa lacuna de experiência parece ter contribuído para a constituição de uma nova identidade, que até então não existia em seu repertório existencial e para a qual ela não se sentia nem um pouco preparada.

Para Monteiro e Lang (2015), há momentos da vida em que é oportuno sair, deixar tudo o que se tem para trás e simplesmente ir embora para começar algo novo. No entanto, na situação de adoecimento, isso nem sempre se faz possível, de forma que a situação deve ser enfrentada com os recursos de que se dispõem. A participante Meire menciona que, a despeito da fadiga e do estresse elevado, não trocaria seu lugar ao lado do filho fragilizado pela possibilidade de fruir uma noite de sono tranquilo:

Não, para mim foi perfeito. Eu sabia que ia ser cansativo, que ia ser estressante, mas eu não troco um dia [chora] do meu cansaço por um dia da vida deles que estão ali em cima daquela cama. [...] É difícil para todo mundo, é cansativo, você quase não dorme, né. E é por isso que eu decidi que eu vou ficar (Meire, 51 anos, mãe de Pedro, diagnosticado com LMC).

Ao redimensionar o sentido de permanecer junto ao paciente, mesmo ao preço do seu desconforto pessoal e da ruptura de sua rotina, o cuidador familiar entende que acompanhar a pessoa adoecida ao longo de todo o processo de hospitalização é um dever moral para com o seu ente querido. Esse sentimento engendra um ganho emocional, que faz com que ele se sinta fortalecido pelo fato de dar conta do dever cumprido. Apesar do sentimento de frustração e do sofrimento inerentes às mudanças abruptas no cotidiano, decorrentes da hospitalização prolongada, o cuidador familiar muitas vezes se sente responsável e na obrigação de permanecer lado a lado com o ente doente, encorajando e auxiliando nas suas dificuldades, fortalecendo a adoção de estratégias de enfrentamento adaptativas e incentivando-o a prosseguir (Passos et al., 2015).

Essa experiência é um processo exaustivo e desgastante, pois exige atenção focalizada e contato prolongado com situações de extrema fragilidade, dor e sofrimento. O altruísmo involucrado nesse papel pode muitas vezes levá-lo a adotar uma atitude estoica frente ao próprio sofrimento, o que pode acentuar ainda mais a sua vulnerabilidade. Por outro lado, o desempenho desse papel pode ser compreendido pelo cuidador como uma prova cabal de sua 
competência, generosidade e disponibilidade, já que o tempo todo a equipe reforça a relevância de sua presença junto ao leito do paciente e requer sua prontidão para atender as diferentes necessidades que surgem no dia a dia. Desse modo, ao se esmerar em desempenhar seu papel da melhor forma possível, buscando atender às expectativas que lhe são depositadas, o acompanhante pode se sentir gratificado e potente como cuidador.

\section{QUANDO A DEVOÇÃO EXAGERADA AO OUTRO IMPÕE O EMPOBRECIMENTO DO AUTOCUIDADO}

Nesse momento é natural haver mudanças de comportamento, uma vez que a atenção não se volta mais para si e sim para o outro adoecido, tal como observado por Passos et al. (2015), que argumentam que o familiar, durante seu período de permanência no hospital, tende a abdicar do cuidado de si para favorecer o bem-estar do paciente. O isolamento é vivido como um fator perturbador tanto pelo doente quanto pelo acompanhante, com a diferença de que este se priva voluntariamente de sair do quarto, entre outros motivos porque tem medo de contrair algum germe que poderia, eventualmente, funcionar como vetor de contaminação do familiar doente.

[...] eu tava conversando com ela: "Nossa, Vera, será que alguma coisa lá de fora? Não quero tanto sair, porque eu tenho medo de sair e vai que a gente traz uma bactéria e afeta você, não sei, acho melhor eu ficar quieta aqui dentro" (Luana, 51 anos, sogra de Vera, diagnosticada com LMC).

Segundo Monteiro e Lang (2015), o devotamento total da atenção para o ente adoecido deixa em aberto a possibilidade da despersonalização do cuidador, que na medida em que passa a viver exclusivamente a vida e a doença do paciente, deixa sua individualidade de lado, como se precisasse negar suas próprias necessidades para estar presente e acompanhar o paciente em um movimento quase autodestrutivo. Isso pode ser fruto de um processo de identificação maciça com a fragilidade do outro. Ao longo dessa trajetória, o familiar cuidador se solidariza o tempo todo com o paciente, apesar do convívio muito próximo com a dor e a doença também fragilizar e desgastar emocionalmente quem desempenha o papel de acompanhante (Passos et al., 2015). O que se observa é o medo de que a expressão aberta de seu sofrimento possa, de alguma forma, potencializar a dor do paciente:

Eu vou para o banheiro - e o banheiro daqui é o meu confessionário - quando eu vejo que vou chorar. Desce aquela água, assim... Eu vou lá no banheiro e minha filha diz: "O que você está fazendo?". "Estou lavando a mão." Aí eu vou, lavo o rosto, seco, coloco a máscara e daí eu acho que ela não percebe, mas quando eu vejo, assim, que eu necessito de chorar, de desabafar, de falar com Deus, eu falo alto para ele me ouvir e aí eu vou para o banheiro, aí eu [pausa] eu deixo as 
lágrimas rolarem. Eu sempre tenho uma estratégia, assim, eu não gosto de chorar na frente dela, eu não gosto de demonstrar que estou preocupada, que eu estou triste, para não deixar ela preocupada, entendeu? (Karla, 40 anos, mãe de Camila, diagnosticada com Esclerose Sistêmica).

Legitimar o sofrimento do familiar e proporcionar espaços seguros e terapêuticos para a livre expressão e cuidado de suas próprias emoções e de outras dimensões subjetivas, são tarefas fundamentais da equipe multiprofissional, uma vez que é reconhecido que o cuidado proporcionado ao familiar acaba repercutindo positivamente na qualidade da atenção que ele poderá oferecer ao paciente, beneficiando também a pessoa adoecida, ainda que de forma indireta (Oliveira-Cardoso et al., 2018a).

O cuidador é uma espécie de sentinela, no sentido de que procura se manter sempre atento às demandas do paciente e da equipe, funcionamento como um elo mediador entre as duas partes. Ao ocupar essa posição especial no cenário hospitalar, exerce um papel fundamental de mediador, buscando dissolver eventuais tensões e evitar que os conflitos que inelutavelmente acompanham a longa trajetória do transplante culminem em polarizações.

\section{ALTERAÇÕES FAMILIARES / SOCIAIS E SUAS REPERCUSSÕES SUBJETIVAS}

Referem-se às mudanças ocorridas durante a vivência do luto antecipatório nos âmbitos familiar e social. Além da família ser impactada com a doença de um de seus membros, ela ainda precisa se manter equilibrada para poder garantir que as necessidades de seus outros integrantes, além do doente, continuem sendo atendidas. A partir disso, pode-se ater à importância de promover, no espaço da assistência, apoio para que haja redistribuição na família dos papéis e responsabilidades (Fonseca, 2014).

\section{REMANEJAMENTOS NECESSÁRIOS NA ORGANIZAÇÃO DA VIDA FAMILAR E SOCIAL}

A busca da cura exige deslocamentos regulares e a mudança de cidade, ao menos temporariamente ( $e$, às vezes, de estado da federação) para cumprir o tratamento. A itinerância e o afastamento de pessoas que exerciam funções importantes na casa exigem a redistribuição de papéis e responsabilidades entre os membros da família, impondo mudanças nas relações estabelecidas entre eles.

Dez dos 11 participantes eram provenientes de outras cidades e precisaram se mudar para o município onde o tratamento era oferecido para poderem acompanhar o parente ao longo das fases do TCTH. A saída de casa envolve muitos sentimentos e perdas. As famílias, de acordo com Rolland (1998), têm de lidar com a perda da vida "normal", da rotina que mantinham antes de receberem o diagnóstico, sendo impelidas a elaborarem o luto pela ruptura do cotidiano 
que tinham enquanto família antes da doença. O pesar é acrescido ainda pelo luto pelo rompimento momentâneo dos sonhos e da esperança no futuro. Dessa forma, a rotina vivida anteriormente precisa ser modificada, a necessidade de hospitalizações frequentes, de realizar exames, tomar medicamentos e submeterse a procedimentos altamente invasivos como o TCTH passam a fazer parte da rotina da família e, principalmente, do familiar cuidador.

Toda a família é de Curitiba, então você vem pra cá, no próprio hospital você fica meio acampado, né. Você não fica confortável, você não tem privacidade nenhuma, até no $10^{\circ}$ andar tem um pouquinho mais de privacidade, já aqui é complicado (Arnaldo, 64 anos, esposo de Elisa, diagnosticada com esclerodermia).

O excerto de fala do participante Arnaldo mostra que, ao longo de sua experiência, o acompanhante tem que lidar não só com um ambiente novo, mas também com um espaço físico que se distancia do aconchego e da sensação de intimidade que se vivencia no lar, acrescido da perda de privacidade, uma vez que a equipe está sempre entrando e saindo sem a menor cerimônia dos quartos. Rocha et al. (2016) mostraram que a rotina desses pacientes, assim como de seus acompanhantes, é abruptamente interrompida, o que ocasiona forte impacto psicossocial devido ao afastamento dos estudos, do emprego, do convívio doméstico e dos demais ambientes de socialização, entre outras perdas que inevitavelmente podem surgir nesse período turbulento da vida familiar.

Eu esperava vir aqui e ficar um mês, não esperava ficar cinco meses. Na minha imaginação, eu viria aqui, ficaria um tempo e depois iria embora, voltaria a arrumar minhas coisas. Agora muita coisa mudou, né. Aqui a gente fica o tempo todo trancafiado num quarto. Eu, antes, tinha uma vida bem diferente, trabalhava, tinha o meu emprego, né (Silvana, 39 anos, irmã de Sandra, diagnosticada com Leucemia Linfóide Aguda - LLA).

Em meio às situações complexas que as famílias vivenciam, vários estados emocionais podem emergir. Os sentimentos podem se apresentar de forma ambivalente ou mesmo caótica, conforme pode ser visto na fala de Silvana, que ao narrar sobre as mudanças ocorridas em sua vida deixa transparecer seu desconforto e sua frustração diante das consequências geradas pelas rupturas em sua rotina. De acordo com Passos et al. (2015), a raiva é um dentre os diversos sentimentos que podem emergir entremeando os dramas vivenciados nesse cenário. Os familiares cuidadores também podem vivenciar sentimentos de tristeza, angústia, medo, culpa e frustração.

Eu vim de Florianópolis, desde o dia 5 de abril eu estou... Eu moro lá, eu tenho meu marido lá, minha casa lá, minhas coisas lá, mas eu estou aqui, você entendeu? Então, foi uma 
transformação total na minha cabeça (Meire, 51 anos, mãe de Pedro, diagnosticado com LMC).

Esse excerto da fala de Meire demonstra que, apesar de sua escolha de permanecer ao lado do filho, exercendo o papel de acompanhante, para ela é sofrido deixar para trás, de forma repentina, a rotina na qual vivia até o momento anterior à internação. A despeito do foco da atenção estar direcionado ao ente adoecido, os familiares ainda mostram preocupação em relação à rotina que mantinham antes da hospitalização, mesmo em meio às incertezas que enfrentam a cada dia quanto ao que será de suas vidas após o tratamento. Que futuro se pode esperar quando se experimenta tantas incertezas em um cenário paradoxal no qual a inconstância é a característica mais estável?

Segundo Andres, Lima e Rocha (2005), o cuidador depara-se com a necessidade de administrar, coordenar e conciliar as novas atividades de cuidados hospitalares com as tarefas do cotidiano familiar, ou seja, ao mesmo tempo em que está junto ao paciente, cuidando, protegendo e atento às suas necessidades, também se preocupa com os afazeres domésticos e como o bem-estar dos outros entes que deixou para trás.

Apesar de receber da equipe do transplante instruções detalhadas sobre o papel do cuidador no acompanhamento do paciente submetido ao TCTH, cada acompanhante só vai aprender a exercer esse papel na prática do cuidar, adaptando-se gradualmente às tarefas:

É difícil, né, porque se fosse lá em São Paulo estaria todo mundo junto, a família junto, né. Mas, infelizmente não foi, nós viemos para cá e se durar 20 dias, vou ficar 20 dias; se durar 100 dias, vão ser 100 dias. É... muda a rotina totalmente. Muda tudo, mas você tem que se adaptar, né? (Rosane, 42 anos, esposa de Paulo, diagnosticado com Mieloma Múltiplo).

A fala de Rosane explicita a situação de crise que se instalou em sua vida, em meio às incertezas que vivencia em relação à duração imprevisível da hospitalização. Além de ter de se adaptar a uma nova rotina, essa participante tem de lidar com a distância da família, o que dificulta a articulação de sua rede de apoio social. É importante que o restante da família se mobilize para oferecer suporte e assistência ao acompanhante, mas nem sempre isso é viável. Por outro lado, para quem permaneceu no lar, é importante ter disponibilidade para assumir e se adaptar à nova rotina sem a presença do cuidador e do membro adoecido, de modo que possam desempenhar novas funções e responsabilidades com a ausência dos familiares.

Mas está sendo difícil para mim, né, porque, assim, meu marido está lá, eu quase não tenho contato com ele. Eu tenho contato, assim, por telefone, né, com meus familiares, você entendeu? [...] Então, está sendo meio difícil viver tudo isso estando praticamente sozinha, né? Eu estou vivendo praticamente 
sozinha, me fortalecendo também (Meire, 51 anos, mãe de

Pedro, diagnosticado com LMA).

Permanecer longe da família pode culminar em um distanciamento nos relacionamentos com aqueles que permanecem no lar, como sugere a fala de Meire, que se dispôs a cuidar do filho fragilizado deixando o marido e os demais filhos para trás. O sacrifício vivido nesse momento se converte em autêntico dilema, pois de um lado há esperança de melhora, mas de outro há sentimentos de desamparo e solidão suscitados por essa vivência prolongada, que impõe rupturas e necessidade de promover uma reorganização das relações familiares.

Foi, assim, meio complicado. A gente teve que mudar totalmente a nossa vida para poder vir para cá, porque eu tenho minhas meninas, uma de 13 e outra de 10 que estava indo lá na minha enteada, tenho a minha filha que está sozinha em casa. Mas a gente se adaptou pra vir todo mundo, pra correr atrás da melhora dele (Rosane, 42 anos, esposa de Paulo, diagnosticado com Mieloma Múltiplo).

O relato de Rosane evidencia a necessidade de promover vários remanejamentos da organização da vida familiar diante da ausência do casal parental. O cenário esboçado é desolador. Para "salvar" o marido adoecido, toda a família vive uma fratura que demanda enorme esforço adaptativo, o que pode acentuar a situação de vulnerabilidade das filhas que se encontram em uma etapa delicada do desenvolvimento. Todos os participantes desta pesquisa comentaram que tiveram que contar com a ajuda de pessoas da família, que passaram a exercer as funções e a se desincumbirem das tarefas e cuidados que antes estavam sob sua responsabilidade. Isso impõe também a necessidade de lidar com as limitações pessoais dos membros da rede familiar.

\section{PERCEPÇÃO DE TRANSFORMAÇÕES PESSOAIS DECORRENTES DO EXERCÍCIO DO PAPEL DE ACOMPANHANTE}

A vivência do papel de acompanhante acarreta mudanças que ultrapassam o imediatismo do momento atual que a pessoa vive. Essas alterações também impactam suas projeções futuras, pois à medida que as perdas irreparáveis vão sucedendo e o medo da morte se intensifica, os familiares passam a reconhecer as próprias necessidades de implementar mudanças em decorrência dos novos papéis que assumem (Fonseca, 2014). Esse processo de mudança envolve maior valorização da vida e do convívio familiar.

Ficar mais com ele, dar mais valor à família, que nem ele [o esposo] falou, outro dia, que vai dar mais valor à família do que a outras coisas materiais (Janaína, 47 anos, esposa de Carlos, diagnosticado com Mieloma Múltiplo).

Estar junto com o paciente na trajetória que se inicia com a descoberta da doença até o momento da alta hospitalar no pós-TCTH imediato faz os 
acompanhantes ressignificarem a própria existência, passando a atribuir maior valor ao próximo e a dar mais atenção às pequenas coisas, abrindo-se para as expressões mais comezinhas da vida.

Agora, assim, aqui é bem diferente. Estando aqui a gente aprende a dar mais valor para as coisas. Assim, não digo só pela minha irmã que está doente, mas pelos outros casos que a gente que está aqui também vê, né (Silvana, 39 anos, irmã de Sandra, diagnosticada com LLA).

[...] hoje eu entendo que a gente precisa de muito pouco para ser feliz, muito pouco. [chora] Você não precisa ter grandes coisas, grandes carros, entendeu? Então, eu acho que às vezes as pessoas estão muito preocupadas: "Aí, ó, porque eu não tenho isso para oferecer, não tenho isso para dar", e de repente aquilo não é importante (Meire, 51 anos, mãe de Pedro, diagnosticado com LMA).

Para alguns familiares, ter passado pela experiência de ser acompanhante no cenário do TCTH oportunizou experiências bastante positivas, uma vez que sentem que receberam apoio e ajuda de pessoas que até então eram desconhecidas, o que os levou a se perceberem como protagonistas de atos e atitudes do mais genuíno altruísmo:

[...] eu vou acreditar mais no amor ao próximo, porque uma pessoa que não te conhece se disponibiliza de tirar uma parte do corpo, uma parte de você para salvar outra vida (Rosane, 42 anos, esposa de Paulo, diagnosticado com Mieloma Múltiplo).

A experiência de ser acompanhante foi transformadora e despertou nesses indivíduos a vontade de retribuírem, pelo menos parcialmente, o que receberam:

Eu estou deixando o meu cabelo crescer porque eu vou doar lá no hospital onde ele fez tratamento, que também atende mulheres que têm câncer de mama, e lá tem uma equipe, umas senhorinhas, tipo uma ONG, aí eles fazem trabalho social, aí a gente faz artesanato lá e eles distribuem para as mulheres (Rosane, 42 anos, esposa de Paulo, diagnosticado com Mieloma Múltiplo).

Igual eu estava falando para o doutor, o meu desejo de muito tempo atrás era de fazer doação. Eu já tinha esse desejo de doar sangue, de doar órgão. Já falei para os meus filhos, quando eu morrer, o que prestar de mim pode tirar (Luana, 51 anos, sogra de Vera, diagnosticada com LMC).

Os relatos mostram que, se por um lado a situação adversa obriga os acompanhantes a redimensionarem seus sonhos e a fazerem adequações nos seus planos, de modo geral eles vislumbram um futuro modificado, com 
possibilidade de levarem a vida de um modo diferente, após revisão de antigos valores e de adquirirem maior disponibilidade para acolherem e ajudarem o próximo.

\section{CONSIDERAÇÕES FINAIS}

A literatura no campo da saúde evidencia que a família é potencialmente a fonte da qual provém o cuidado, que é realizado normalmente pelas mulheres, embora os cuidadores masculinos também estejam presentes no processo de hospitalização de crianças e adolescentes, e também de esposas (Floriani, 2014). Ainda que o presente estudo conte com uma amostra de conveniência composta por 11 participantes, foi majoritariamente constituída por mulheres, tendo participado apenas dois homens, o que reflete a realidade que se observa empiricamente na unidade hospitalar onde a pesquisa foi desenvolvida. Assim, o fato de a maioria dos colaboradores deste estudo serem mulheres vai ao encontro do esperado e se coaduna com a lógica de que cuidar de pessoas doentes é um fenômeno generificado.

As entrevistas realizadas comprovam que permanecer junto ao paciente que é submetido ao TCTH ao longo do período de hospitalização envolve uma série de perdas e rupturas da vida que se levava antes do adoecimento do membro familiar. O sentimento de ruptura que esse processo desencadeia, mesmo que transitório, deixa marcas profundas na vida pessoal e familiar do acompanhante. A vivência de dilaceramento do cuidador familiar permeia toda a travessia do transplante. O momento de maior angústia vivido pelos entrevistados foi quando receberam o diagnóstico do ente querido. Segundo Oliveira-Cardoso et al. (2018b), o período que abrange a descoberta dos primeiros sintomas e o estabelecimento do diagnóstico médico e o início do tratamento pode ser considerado o momento mais crítico enfrentado por essas pessoas, uma experiência emocionalmente dolorosa, que é perpassada por sintomas de ansiedade, inquietação e estresse familiar.

Nesse momento já se iniciam os primeiros sinais do luto antecipatório. Nesse processo os sentimentos e a atenção dos acompanhantes passam a ser deslocados e se concentram no paciente, gerando diversas reações compatíveis com o processo de luto. O risco de vida imposto pela doença se vê acrescido do desafio representado pela necessidade de sobreviver ao tratamento. Nesse cenário paradoxal os acompanhantes alternam entre a esperança de obterem sucesso no tratamento, com a consequente melhora do ente adoecido, e o cansaço crônico favorecedor da desesperança e do desalento. Flutuando entre essas polaridades, o familiar vivencia a ambivalência de seus sentimentos. Assim, diante da possibilidade palpável da morte e perda do ente adoecido, o membro saudável frui também de momentos de esperança como parte das dimensões emocionais que se fazem presentes no luto antecipatório.

O luto está associado a um sentimento profundo de perda e tristeza, contudo, no que concerne ao cuidador familiar no contexto do TCTH, seu consternamento e 
suas aflições podem não ser ouvidas. Com isso o processo de pesar e luto não pode se completar. Por esse motivo, o profissional de saúde precisa ser capacitado a identificar os sinais de luto antecipatório do cuidador, por meio da compreensão empática, sensibilizando-se com sua dor e sofrimento.

Os participantes cujos familiares passaram por transplante alogênico, no qual o doador é uma terceira pessoa que pode ou não ser aparentada, vivenciaram o processo de luto antecipatório de forma similar aos que tiveram o ente doente submetido ao transplante autólogo, no qual o procedimento se dá reutilizando a medula do próprio paciente. No entanto, as incertezas despertadas diante da impossibilidade de encontrar um doador compatível, nos casos do transplante alogênico, foram consideradas como um fator agravante do sofrimento que o conhecimento do diagnóstico suscita.

As dificuldades presentes ao longo do período de hospitalização, no qual o acompanhante abdica integralmente de um quinhão de sua vida para exercer o papel de cuidador em tempo integral, também abrangem, no contexto psicossocial, a esfera financeira. Estudo realizado por Floriani (2014) mostrou que a erosão financeira do cuidador e da família é um dado concreto que atinge, principalmente, as famílias de baixa renda. A análise dos temas recorrentes nas entrevistas realizadas neste estudo comprovou esse dado da literatura, pois os cuidadores que desfrutavam de melhor condição financeira, marcada por cargos empregatícios mais qualificados, conseguiram afastamento de seus postos de trabalho, enquanto que os familiares que tinham ocupações relacionadas a menor prestígio social e baixo rendimento, enfrentavam maiores dificuldades de prover suas necessidades materiais, uma vez que os cuidadores tiveram que deixar seus empregos.

Outro aspecto que merece ser considerado neste estudo é a relevância da equipe multidisciplinar, formada por psicólogos, profissionais de enfermagem e médicos, no que concerne ao fornecimento de suporte psicossocial não somente ao paciente hospitalizado, mas também ao familiar acompanhante. Os participantes desta pesquisa descrevem a importância do suporte recebido, até mesmo para tornar o ambiente estressante do hospital um espaço mais agradável para se conviver, fazendo com que se sintam menos desconfortáveis. Esse dado está em conformidade com o que Contel et al. (2000) descreveram acerca do impacto positivo que o acolhimento da equipe desencadeia, o que contribui para reduzir a escalada de tensões inerentes ao tratamento do paciente hospitalizado para realização do TCTH.

Ademais, percebe-se que, por se tratar de um serviço inserido em um hospital universitário de referência nacional, no qual há um fluxo enorme de pacientes e volume intenso de procedimentos realizados como rotina, essas características possibilitaram que nesta pesquisa fosse avaliada uma diversidade de participantes em relação ao grau de parentesco com o ente adoecido. Dessa forma, foi possível avaliar a conexão do sofrimento não só da família de origem 
(por exemplo, mães), mas também da família constituída e expandida (por meio da inclusão de cônjuges e sogra).

Um achado inovador deste estudo foi o de que os familiares, depois de vivenciarem o processo inicial do enlutamento, que envolveu choque, ruptura do cotidiano, perdas emocionais e físicas, necessidade de revisão dos papéis familiares e sociais, imersão em uma rotina intensa de cuidados, mostraram-se permeáveis à mudança e abertos à reflexão sobre a forma como viveram suas vidas até aquele momento. Demonstraram ter consciência da possibilidade de confrontarem a perda do ente querido em seu horizonte existencial, sem que isso resultasse em desengajamento da própria vida; pelo contrário, isso pareceu fazêlos se apegarem à esperança e realimentarem sonhos e desejos de desfrutarem de uma vida mais leve e de um futuro melhor. Os dados sugerem que os cuidadores conseguiram ir além do aprisionamento imposto pelas contingências adversas do momento presente, projetando-se em um futuro que pode ser pensado e transformado. Desse modo, a despeito de enfrentarem medo e desesperança no decorrer do percurso, passaram a conviver também com sentimentos de gratidão e altruísmo.

Realizar este estudo sobre as repercussões psicológicas do papel de cuidador integral durante o processo de hospitalização de paciente submetido ao TCTH possibilitou um conhecimento mais aprofundado e um olhar mais crítico e ao mesmo tempo mais sensível para esse tema. As entrevistas realizadas para a viabilização desta investigação também proporcionaram a criação de um espaço de acolhimento para o acompanhante, no qual os participantes puderam discorrer livremente sobre suas angústias, temores, dúvidas, expectativas e demais sentimentos e questões que surgiram em meio à narração de como desenharam suas trajetórias como cuidadores. O estudo da experiência dos cuidadores contribui, secundariamente, para destacar a importância da oferta de programas e intervenções psicológicas dentro da UTMO, sejam elas individuais ou grupais, destinadas aos familiares.

Em uma aproximação metafórica, o TCTH pode ser comparado à chama da vela que, embora bruxuleante, ainda não se apagou, o que possibilita que pacientes e cuidadores mantenham viva a esperança de cura após amargarem várias tentativas de tratamento que resultaram em insucesso. O trabalho com as manifestações de luto vivenciadas pelos cuidadores ao longo de todo o processo é importantíssimo, pois permite que o sofrimento seja elaborado e validado. 0 trabalho com o luto antecipatório dentro da UTMO, quando permite olhar, cuidar e legitimar os sentimentos do familiar, proporciona um espaço para que as pessoas tenham sua subjetividade preservada e suas dores ressignificadas.

Assim, propõe-se que sejam realizadas mais pesquisas nessa área, pois o estudo do impacto psicológico causado pelo período em que o acompanhante se mantém isolado na UTMO pode contribuir no sentido de aprimorar as intervenções realizadas no cuidado a essas pessoas face às suas vulnerabilidades. 
O estudo acompanhou os participantes apenas em um momento ao longo do período de hospitalização, o que pode ser visto como uma limitação. Acredita-se que uma análise realizada em diferentes momentos do tratamento poderia introduzir novos resultados, que contribuiriam para ampliar a compreensão do processo como um todo. Sugere-se também realizar estudos semelhantes em outras unidades de TCTH para saber se os achados podem ser generalizados para contextos que sejam diferentes das condições que se tem em um hospital de referência.

\section{REFERÊNCIAS}

Alves-Mazzoti, A. J. (2006). Usos e abusos dos estudos de caso. Cadernos de Pesquisa, 36(129), 637651. doi:10.1590/S0100-15742006000300007.

Andres, J. C., Lima, R. A. G., \& Rocha, S. M. M. (2005). Experiência de pais e outros familiares no cuidado à criança e ao adolescente após o transplante de medula óssea. Revista Brasileira de Enfermagem, 58(4), 416-421.

Braun, V., \& Clark, V. (2006). Using thematic analysis in psychology. Qualitative Research in Psychology, 3(2), 77-101.

Contel, J. O. B., Sponholz Jr, A., Torrano-Masetti, L. M., Almeida, A. C., Oliveira, E. A., Jesus, J. S., ... Voltarelli, J. C. (2000). Aspectos psicológicos e psiquiátricos do transplante de medula óssea. Medicina Ribeirão Preto, 33, 294-311.

Diefencach, G. D. F., Toscan, P. B., \& Pavão, S. M. O. (2008). Cuidado ao familiar cuidador do paciente submetido a transplante de medula óssea. Ciência, Cuidado e Saúde, 7(1), 61-65.

Floriani, C. A. (2004). Cuidador familiar: sobrecarga e proteção. Revista Brasileira de Cancerologia, 50(4), 341-345.

Fonseca, J.P. (2014). Luto antecipatório: situações que se vivem diante de uma morte anunciada. In: F. S. Santos (Ed.), Tratado brasileiro sobre perdas e lutos (pp. 145-154). São Paulo: Atheneu.

Freitas, I. S., Cardoso, E. A. O., \& Santos, M. A. (2013). Espiritualidade e religiosidade em mães de crianças com câncer hematológico. Psicologia em Estudo (Maringá), 22(1), 433-447.

Guimarães, F. A. B., Cardoso, E. A. O., Mastropietro, A. P., Voltarelli, J. C., \& Santos, M. A. (2010). Impact of autologous hematopoetic stem cell transplantation on the quality of life of patients with multiple sclerosis. Arquivos de Neuro-Psiquiatria, 68(1), 522-527.

Matsubara, T. C., Carvalho, E. C., Canini, S. R. M. S., \& Sawada, N. O. (2007). A crise familiar no contexto do transplante de medula óssea (TMO): uma revisão integrativa. Revista LatinoAmericana de Enfermagem, 15(4), 665-670.

Monteiro, S., \& Lang, C. S. (2015). Acompanhamento psicológico ao cuidador familiar de paciente $\begin{array}{llll}\text { oncológico. Psicologia } \quad \text { Argumento, 33(83), } & \text { 483-495. }\end{array}$ doi:10.7213/psicol.argum.33.083.AO04.

Oliveira, E. A., Voltarelli, J. C., Santos, M. A., \& Mastropietro, A. P. (2005). Intervenção junto à família do paciente com alto risco de morte. Medicina (Ribeirão Preto), 38(1), 63-68.

Oliveira-Cardoso, E. A., \& Santos, M. A. (2013). Luto antecipatório em pacientes com indicação para o Transplante de Células-Tronco Hematopoéticas. Ciência \& Saúde Coletiva, 18(9), 25672575. doi:10.1590/S1413-81232013000900011.

Oliveira-Cardoso, E. A., Garcia, J. T., Guimarães, A. L. C., Pereira-Martins, M. L., P. L., Santos, J. H., \& Santos, M. A. (2018a). Quality of life after bone marrow transplantation: comparison between evalution of chidrens and mothers. Revista Família, Ciclos de Vida e Saúde no Contexto Social - REFACS, 6(1), 686-693.

Oliveira-Cardoso, E. A., Garcia, J. T., Lotério, L. S., \& Santos, M. A. (2018b). Comunicando más notícias em um hospital geral: a perspectiva do paciente. Revista da SPAGESP, 19(1), 90102.

Pasquini, R., \& Coutinho, E. (2013). Fundamentos e biologia do Transplante de Células-Tronco Hematopoéticas. In: M. A. Zago, R. P. Falcão, \& R. Pasquini (Eds.), Tratado de hematologia (pp. 711-729). São Paulo: Atheneu. 
Pontes, L., Guirardello, E. B., \& Campos, C. J. G. (2007). Demandas de atenção de um paciente na unidade de transplante de medula óssea. Revista da Escola de Enfermagem USP, 41(1), 154-160. doi:10.1590/S0080-62342007000100021.

Riul, S., \& Aguillar, O. M. (1997). Contribuição à organização de serviços de transplante de medula óssea e a atuação do enfermeiro. Revista Latino-Americana de Enfermagem, 5(1), 49-58. doi:10.1590/S0104-11691997000100006.

Rocha, V., Proença, S. F. F. S., Marques, A. C. B., Pontes, L., Mantovani, M. F., Kalinke, L. P. (2016). Comprometimento social de pacientes submetidos ao transplante de células-tronco hematopoéticas. Revista Brasileira de Enfermagem, 69(3), 484-491. doi:10.1590/00347167.2016690310i.

Rolland, J. S. (1998). Ajudando as famílias com perdas antecipadas. In: F. Walsh \& M. McGoldrick (Eds.), Morte na família: Sobrevivendo às perdas (O. Dornelles, trad., pp. 166-186). Porto Alegre, RS: ArtMed.

Sá, M. A. N. (2002). Um estudo sobre cuidadores familiares de pacientes internados com doenças hematológicas. Psic: Revista da Vetor Editora, 3(1), 124-141.

Sampaio, A. S. (2011). Cuidando do cuidador: Perspectiva de atuação psicológica em uma casa de apoio. Psicologia Argumento, 29(67), 491-498.

Simoneau, T. L., Mikulich-Gilbertson, S. K., Natvig, C., Kilbourn, K., Spradley, J., Grzywa-Cobb, R. ... Laudenslager, M. L. (2013). Elevated peri-transplant distress in caregivers of allogeneic blood or marrow transplant patients. Psychooncology, 22(9), 2064-2070. doi:10.1002/pon.3259.

Silva, B. C. A., Santos, M. A., \& Oliveira-Cardoso, E. A. (2019). Vivências de familiares de pacientes com câncer: Revisitando a literatura. Revista da SPAGESP, 20(1), 140-153.

Passos, S. S. S., Pereira, A., \& Nitschke, R. G. (2015). Cotidiano do familiar acompanhante durante a hospitalização de um membro da família. Acta Paulista de Enfermagem, 28(6), 539-545. doi:10.1590/1982-0194201500090.

Von Ah, D., Spath, M., Nielsen, A., \& Fife, B. (2015). The caregiver's role across the bone marrow transplantation trajectory. Cancer Nursing, 39(1), E12-E19. doi:10.1097/NCC.0000000000000242.

Weber, F. (2009). A entrevista, a pesquisa e o íntimo, ou por que censurar seu diário de campo? Horizontes Antropológicos, 15(32), 157-170. doi:10.1590/\$0104-71832009000200007

\section{AGRADECIMENTOS}

Os autores agradecem à equipe da Unidade de Transplante de Medula Óssea do Hospital das Clínicas da Faculdade de Medicina de Ribeirão Preto da Universidade de São Paulo, pelo apoio na coleta de dados e pela excelência na formação em serviço de profissionais de diferentes áreas de especialidade.

\section{CONFLITOS DE INTERESSES}

Os autores declararam que não houve conflitos de interesses para realização desta pesquisa.

\section{FINANCIAMENTO}

Conselho Nacional de Desenvolvimento Científico e Tecnológico - CNPq, por meio de Bolsa de Produtividade em Pesquisa PQ-1A.

Universidade de São Paulo - USP, por meio de Bolsa do Programa Unificado de Bolsas de Estudos para Apoio e Formação de Estudantes de Graduação (PUB-USP).

\section{SOBRE OS AUTORES}

Thaísa dos Santos Madeira é psicóloga formada pelo curso de Psicologia da Faculdade de Filosofia, Ciências e Letras de Ribeirão Preto da Universidade de São Paulo (FFCLRP-USP). Membro do Laboratório de Ensino e Pesquisa em Psicologia da Saúde - LEPPS (FFCLRP-USP-CNPq). Bolsista do Programa Unificado de Bolsas de Estudos para Apoio e Formação de Estudantes de Graduação da 
Universidade de São Paulo (PUB-USP). Trabalha no campo da Psicologia da Saúde nas interfaces família e enfrentamento do processo saúde-doença.

E-mail: thaisamadeira@hotmail.com

(1) https://orcid.org/0000-0002-1201-0316

Érika Arantes de Oliveira-Cardoso é Professora Doutora do Programa de Pós-Graduação em Psicologia da Faculdade de Filosofia, Ciências e Letras de Ribeirão Preto da Universidade de São Paulo (FFCLRP-USP). É psicóloga, mestre e doutora pelo Programa de Pós-Graduação em Psicologia da FFCLRP-USP. Especialista em Psicologia Hospitalar pelo Conselho Federal de Psicologia (CFP). Vice-coordenadora do Laboratório de Ensino e Pesquisa em Psicologia da Saúde - LEPPS (FFCLRPUSP-CNPq). Trabalha no campo da Psicologia da Saúde, nas interfaces enfrentamento do processo saúde-doença, diversidade de orientaç̃es sexuais e identidades de gênero.

E-mail: erikaao@ffclrp.usp.br

\section{https://orcid.org/0000-0001-7986-0158}

Manoel Antônio dos Santos é Professor Titular da Faculdade de Filosofia, Ciências e Letras de Ribeirão Preto da Universidade de São Paulo. É psicólogo, mestre e doutor em Psicologia Clínica pelo Instituto de Psicologia da Universidade de São Paulo (IP-USP). Coordenador do Laboratório de Ensino e Pesquisa em Psicologia da Saúde - LEPPS (FFCLRP-USP-CNPq). Trabalha no campo da Psicologia da Saúde, nas interfaces processo saúde-doença, família, gênero e diversidade sexual. É bolsista de Produtividade em Pesquisa PQ-1A do Conselho Nacional de Desenvolvimento Científico e Tecnológico - CNPq.

E-mail: masantos@ffclrp.usp.br

(1) https://orcid.org/0000-0001-8214-7767 